Article

\title{
Growth and Expression of Virulence Genes of Listeria monocytogenes during the Processing of Dry-Cured Fermented "Salchichón" Manufactured with a Selected Lactilactobacillus sakei
}

\author{
Irene Martín (D), Alberto Alía (D, Alicia Rodríguez *, Francisco Gómez and Juan J. Córdoba (1) \\ Food Hygiene and Safety, Meat and Meat Products Research Institute, Faculty of Veterinary Science, University of \\ Extremadura, Avda. de las Ciencias, s/n, 10003 Cáceres, Spain; iremartint@unex.es (I.M.); \\ albertoam@unex.es (A.A.); fgmzpo@unex.es (F.G.); jcordoba@unex.es (J.J.C.) \\ * Correspondence: aliciarj@unex.es
}

Citation: Martín, I.; Alía, A.; Rodríguez, A.; Gómez, F.; Córdoba, J.J. Growth and Expression of Virulence Genes of Listeria monocytogenes during the Processing of Dry-Cured Fermented "Salchichón" Manufactured with a Selected Lactilactobacillus sakei. Biology 2021, 10, 1258. https://doi.org/10.3390/ biology10121258

Academic Editors: Huizhong Chen and Cormac Gahan

Received: 6 October 2021

Accepted: 30 November 2021

Published: 2 December 2021

Publisher's Note: MDPI stays neutral with regard to jurisdictional claims in published maps and institutional affiliations.

Copyright: (C) 2021 by the authors. Licensee MDPI, Basel, Switzerland. This article is an open access article distributed under the terms and conditions of the Creative Commons Attribution (CC BY) license (https:// creativecommons.org/licenses/by/ $4.0 /)$.
Simple Summary: During the ripening process of the dry-cured fermented sausage "salchichón", Listeria monocytogenes could fail to be eliminated. In addition, the food safety criterion for L. monocytogenes in the European Union sets up a maximum level of 100 units of this microorganism per gram in ready-to-eat products throughout their shelf-life. Thus, since L. monocytogenes could be present in this product, it is necessary to evaluate the impact of the dry-cured fermented processing in the potential virulence of this pathogen, even considering the possible effect of the usual microbiota (lactic-acid bacteria) of "salchichón". In this work, the effect of the processing of "salchichón", inoculated with a selected strain of Lactilactobacillus sakei, on the growth of L. monocytogenes and on the expression of its virulence genes, was evaluated. The processing of "salchichón" provoked a relevant reduction in L. monocytogenes, but this pathogen was not completely eliminated. However, a downregulation in the expression of the tested virulence genes was found, which could suppose a reduction in the pathogenic effect of this microorganism. These findings could be of great interest to consider the dry-cured ripening of "salchichón" as a safe process to control the pathogen L. monocytogenes.

Abstract: The effect of the dry-cured fermented processing of "salchichón" inoculated with a selected strain of Lactilactobacillus sakei (205) on the growth and transcriptional response of three virulence genes ( $p l c A, h l y$, and iap) of Listeria monocytogenes was evaluated. For this, three different batches of "salchichón" were analyzed: batch B (inoculated only with L. sakei), batch L (inoculated only with L. monocytogenes), and batch L + B (inoculated with both microorganisms). Sausages were ripened for 90 days according to a traditional industrial process. The processing of "salchichón" provoked a reduction in L. monocytogenes counts of around $2 \log \mathrm{CFU} / \mathrm{g}$. The downregulation of the expression of the three genes was found at the end of ripening when the water activity $\left(\mathrm{a}_{\mathrm{w}}\right)$ of "salchichón" was $<0.85 \mathrm{a}_{\mathrm{w}}$. The combined effect on the reduction in L. monocytogenes counts together with the downregulation in the expression of the virulence genes throughout the "salchichón" processing could be of great interest to control the hazard caused by the presence of this pathogenic bacterium.

Keywords: Listeria monocytogenes; dry-cured fermented sausage; Lactilactobacillus sakei; virulence gene expression

\section{Introduction}

L. monocytogenes is a Gram-positive, facultative intracellular bacterium responsible for human listeriosis, one of the most significant foodborne diseases in industrialized countries [1] that has well-known adverse health effects [2]. L. monocytogenes may contaminate food products at different steps of the manufacturing process, since this organism is able to survive on equipment and in production facilities $[3,4]$. It has been also reported that 
L. monocytogenes can pull through stressful environments, such as low temperature, high acidity, and salt contents $[2,5,6]$. This ability is a serious concern for the dry-cured fermented sausage industry. This is because dry-cured fermented meat products elaborated with meat and fat, mixed with salt, nitrate and/or nitrite, sugar, and spices like black pepper, which is stuffed into a casing and subjected to fermentation and drying processes, form a nutrient-rich but still restricted ecological niche that can favour the growth of $L$. monocytogenes [7].

The dry-cured fermented sausage "salchichón" is one of the most typical Spanish dry-cured meat ready-to-eat (RTE) products, characterized by a bacterial fermentation process followed by a ripening period [8]. Although the consumption of dry-cured fermented sausages is considered at low risk for foodborne listeriosis [9], the presence of this pathogenic bacterium has been reported in ripened sausages [10-12], and in some cases, it has also been involved in listeriosis outbreaks [13].

During the ripening of dry-cured fermented sausages such as "salchichón", a reduction of $L$. monocytogenes has been reported, but its presence has not been completely eliminated [14]. In addition, the food safety criterion for L. monocytogenes sets up a maximum level of $100 \mathrm{CFU} / \mathrm{g}$ for this pathogen in RTE-food products throughout their shelf-life [15].

Since L. monocytogenes can be present in the dry-cured fermented sausage "salchichón", it is necessary to evaluate the impact of the dry-cured fermented processing on the potential virulence of this pathogen. The intracellular parasitism of $L$. monocytogenes requires the coordinated expression of several genes that encode virulence factors, such as the $p l c A$, $h l y$, and iap genes [16]. The transcriptional response of $L$. monocytogenes under a variety of $\mathrm{pH}$, water activity $\left(\mathrm{a}_{\mathrm{w}}\right)$, temperature conditions $[17,18]$, or upon exposure to protective cultures [19] could result in changes in the L. monocytogenes viability and virulence [20-25].

To evaluate changes in the L. monocytogenes virulence during the processing of "salchichón", the usual microbiota present in this product should be considered. This is mainly composed of lactic-acid bacteria (LAB) such as Lactilactobacillus spp. together with yeast and moulds [26]. LAB in conjunction with fermentation and ripening processes contributes to the organoleptic characteristics of the products as well as their stability [27-29]. Lactilactobacillus sakei is the most frequently isolated LAB in meat products, in particular on dry-cured fermented sausages [8,30-35] whose main functions in sausage fermentation are the acidification and inhibition of undesired autochthonous microbiota [36]. This bacterium can grow and survive under the conditions encountered during meat storage and processing [37]. In fact, L. sakei possesses the ability to use nutrients encountered in meat [30]. Furthermore, it has been proposed as a protective culture against L. monocytogenes in dry-cured fermented sausages [38-40].

Current knowledge regarding the effect of an antagonistic $L$. sakei strain against $L$. monocytogenes should be integrated with information concerning the molecular response of the pathogen to such treatments. Therefore, the objective of this work was to investigate the effect of the processing of the dry-cured fermented sausage "salchichón", inoculated with a selected strain of $L$. sakei, on the growth of L. monocytogenes and the transcriptional response of some of its virulence genes ( $p l c A, h l y$, and iap).

\section{Materials and Methods}

\subsection{Bacterial and Culture Conditions}

To evaluate the effect of the processing of "salchichón" on the growth and expression of the key virulence genes of L. monocytogenes, a strain of serotype $4 \mathrm{~b}$ isolated from drycured meat products was used, since this serotype is the most frequently involved in clinical cases of listeriosis. In addition, this serotype has been reported as the highest transcriptomic response under hostile environments [41]. Thus, the strain L. monocytogenes S7-2 (serotype $4 \mathrm{~b}$ ), belonging to the National Institute of Agricultural and Food Research and Technology (INIA) collection (Madrid, Spain), has been used for the inoculation of "salchichón". 
To evaluate the effect on LAB against L. monocytogenes, a selected strain of L. sakei 205 from the Food Hygiene and Safety Culture Collection at the University of Extremadura was used. This strain was isolated from traditional dry-cured fermented sausages and selected by its antagonistic activity against L. monocytogenes in a sterilized "salchichón"based agar and in the dry-cured fermented sausages "salchichón" [14]. Thus, in the present work, the effect of the selected $L$. sakei strain on the expression of the virulence genes of $L$. monocytogenes in a real food system (dry-cured fermented "salchichón") in the presence of the natural microbiological population of this product was evaluated.

To prepare the L. monocytogenes and LAB inocula, $100 \mu \mathrm{L}$ of a stock culture (stored in Brain Heart Infusion (BHI) broth (Pronadisa, Madrid Spain) containing $20 \%(w / v)$ glycerol at $-80^{\circ} \mathrm{C}$ ) was sub-cultured twice onto BHI broth at $37^{\circ} \mathrm{C}$ for $24 \mathrm{~h}$ and Man Rogosa Sharpe (MRS) broth (Fisher Bioreagents, Belgium) at $30^{\circ} \mathrm{C}$ for $48 \mathrm{~h}$, respectively (Figure 1 ). At the end of the incubation period, a suspension containing $\approx 8.0 \log \mathrm{CFU} / \mathrm{mL}$ cells was obtained and an aliquot of this was diluted in $1 \%(w / v)$ peptone water to reach final concentrations of $\approx 7.0$ and $6.0 \log \mathrm{CFU} / \mathrm{mL}$ for L. monocytogenes and L. sakei, respectively. Next, after centrifuging cultures at $10,000 \times g$ for $5 \mathrm{~min}$, the supernatants were discarded, and the sediments were washed and resuspended in PBS to be used for the inoculation of the "salchichón" mix before stuffing. To check the level of inoculation, serial dilutions were plated onto Chromagar ${ }^{\mathrm{TM}}$ Listeria agar plates (Scharlab, Madrid, Spain) and incubated at $37^{\circ} \mathrm{C}$ for $48 \mathrm{~h}$ for L. monocytogenes, while for LAB, dilutions were spread on MRS (Oxoid, Basingstoke, UK) agar plates and anaerobically incubated at $30^{\circ} \mathrm{C}$ for $72 \mathrm{~h}$. In addition, the real initial levels (log CFU/g) of L. monocytogenes and L. sakei 205 on the sausages were determined at day 0 of processing.

\subsection{Elaboration of Dry-Cured Fermented "Salchichón"}

The "salchichón" sausages were elaborated in a pilot plant located at the Faculty of Veterinary of the University of Extremadura (Spain) according to the industrial processing of this product [14], the mixture composition proceeding as follows: minced Iberian pork meat $(90 \%)$ and Iberian pig fatback $(7 \%)$, with an addition of $\mathrm{NaCl}(1.8 \%)$, cane sugar $(0.4 \%)$, potassium nitrate $(120 \mathrm{ppm})$, sodium nitrite (100 ppm), black pepper, and spices (Figure 1). This mixture was divided into 3 different batches, to which $150 \mathrm{~mL}$ of PBS with the corresponding microorganism's inoculum, prepared as has been described in Section 2.1, were added. The three batches were: batch B (control inoculated only with $L$. sakei at a concentration of $\approx 6 \log C F U / g$ ); batch $\mathrm{L}$ (inoculated only with $L$. monocytogenes at a concentration of $\approx 7 \log \mathrm{CFU} / \mathrm{g}$ ); batch $\mathrm{L}+\mathrm{B}$ (inoculated with $L$. monocytogenes at a concentration of $\approx 7 \log \mathrm{CFU} / \mathrm{g}$ combined with $L$. sakei at a concentration of $\approx 6 \log \mathrm{CFU} / \mathrm{g}$ ). All ingredients and corresponding inoculum were then mixed using an automatic kneader that was cleaned and sanitized between batches. The mixes of the different batches were then stuffed into regenerated collagen casings of $40 \mathrm{~mm}$ in diameter (Viscofan, Navarra, Spain), reaching each sausage an approximate weight of $500 \mathrm{~g}$.

The sausages were ripened for 90 days in controlled drying chambers of the pilot plant of the Faculty of Veterinary Science following the conditions used in typical traditional processing of "salchichón" [14]: $5^{\circ} \mathrm{C}$ at $85 \%$ relative humidity (RH) for 3 days, then $7{ }^{\circ} \mathrm{C}$ and $80 \% \mathrm{RH}$ for the 17 days, $9{ }^{\circ} \mathrm{C}$ and $75 \% \mathrm{RH}$ for 10 days, and $12{ }^{\circ} \mathrm{C}$ and $70 \% \mathrm{RH}$ to reach 90-day ripening (Figure 1).

For physicochemical, microbial, and gene expression analyses, five sausages of each batch were taken at the beginning of processing (day 0 ) and at 15, 30, 45, 60, and 90 days of ripening. All of them were aseptically removed from the casings in a laminar flow cabinet (Telstar, Spain) before analytical determinations. Thus, the experiment consisting of 3 different batches $\times 5$ sampling times $\times 5$ different analyzed sausages/each batch and sampling time was evaluated once according to the European Union Reference Laboratory Technical Guidance Document for conducting shelf-life studies on L. monocytogenes in RTE foods (such as "salchichón"), where no growth or the growth probability of this pathogen is $\leq 10 \%[42]$. 


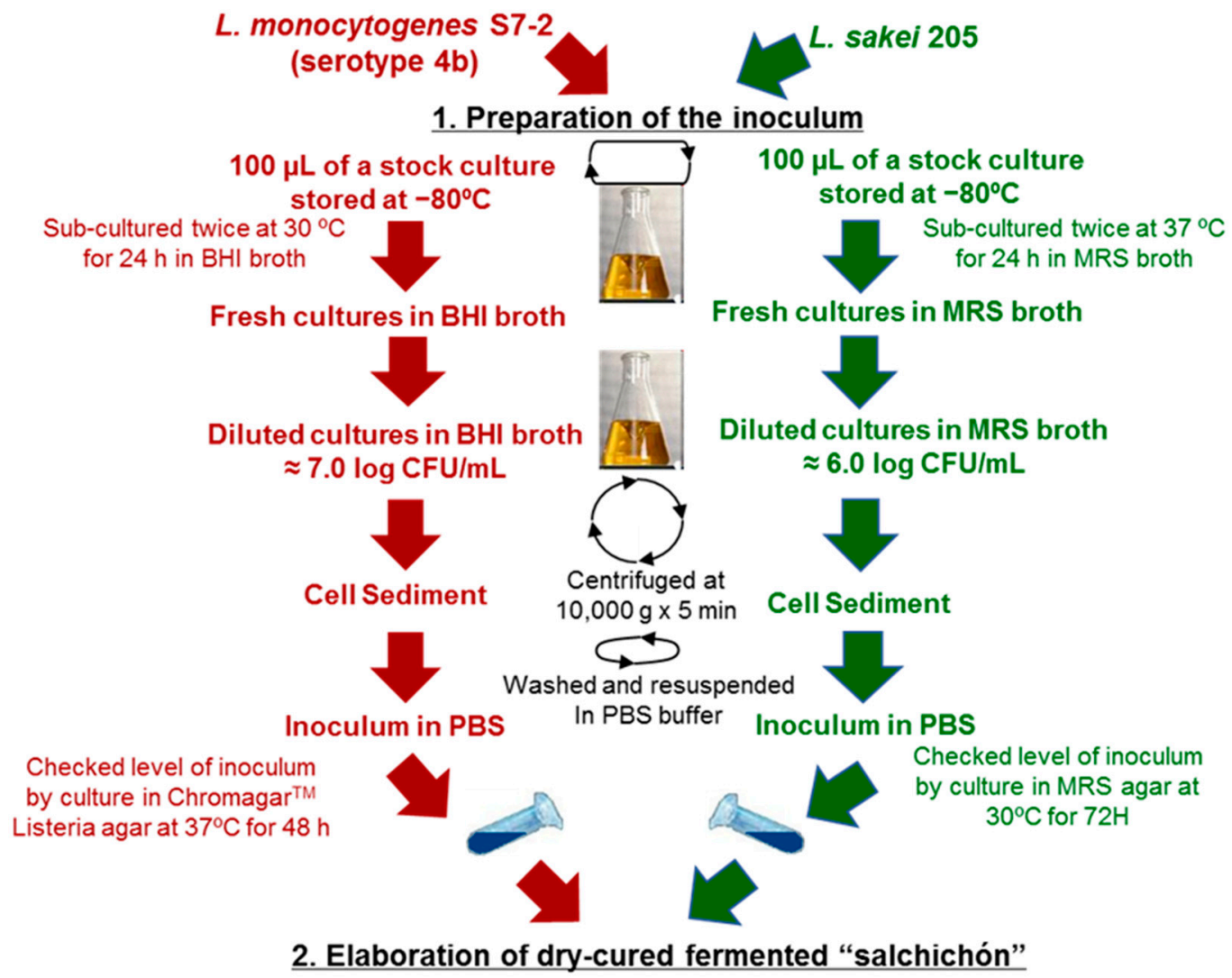

Mixed of ingredients ( $90 \%$ lberian pork meat, $7 \%$ lberian pig fatback, $1.8 \% \mathrm{NaCl}, 0.4 \%$ sugar, $120 \mathrm{ppm}$ potassium nitrate, $100 \mathrm{ppm}$ sodium nitrite, black pepper and spices

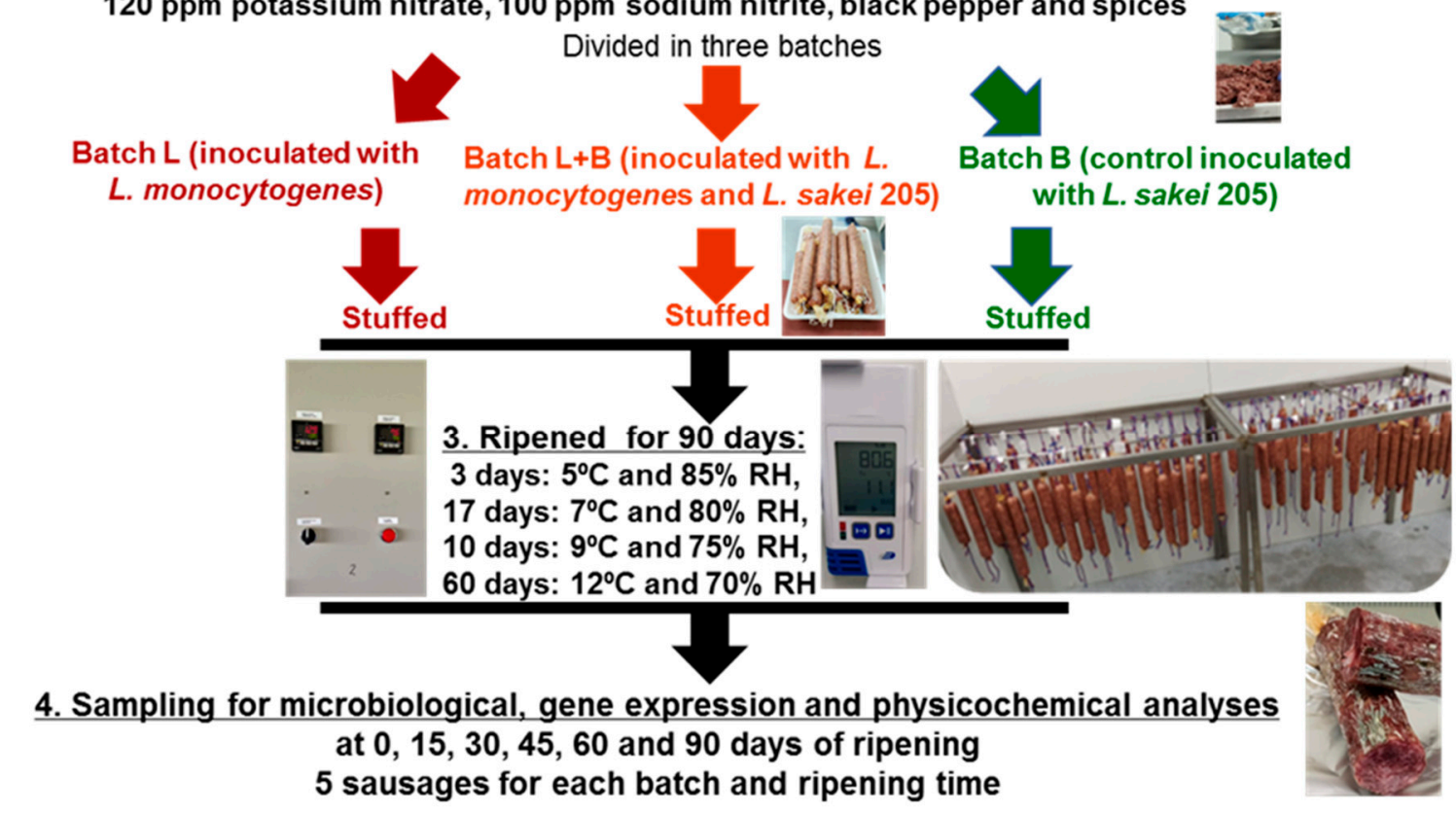

Figure 1. Scheme of the methodology followed in this work for preparing the inoculum, elaboration, and ripening conditions of the inoculated "salchichón" and sampling.

\subsection{Microbiological Analysis}

At each sampling time, $10 \mathrm{~g}$ of each of the 5 dry-cured sausages "salchichón" were aseptically taken from the center of the product and mixed with $90 \mathrm{~mL}$ of $1 \%(w / v)$ peptone water and homogenized in a Stomacher machine (Seward, model 400 Circulator, West Sussex, UK) at $300 \mathrm{rpm}$ for $1 \mathrm{~min}$. One $\mathrm{mL}$ of this homogenate was frozen at $-80{ }^{\circ} \mathrm{C}$ and 
stored for further RNA extraction and gene expression analysis. Another one $\mathrm{mL}$ aliquot was used to make serial dilutions for the estimation of L. monocytogenes and LAB counts. For this, decimal serial dilutions were subsequently carried out in $1 \%(w / v)$ of peptone water, and $100 \mu \mathrm{L}$ of the cell suspensions were then spread onto the surface of the MRS agar and CHROMagar ${ }^{\mathrm{TM}}$ Listeria Chromogenic medium to determine $\mathrm{LAB}$ counts and $L$. monocytogenes, respectively. Their incubation was performed for $24-48 \mathrm{~h}$ at $30^{\circ} \mathrm{C}$ for LAB counts and for $24-48 \mathrm{~h}$ at $37^{\circ} \mathrm{C}$ for L. monocytogenes counts. To evaluate the implantation of L. sakei 205 in all batches and at the last sampling time (90 days), 50\% of the characteristic $\mathrm{LAB}$ colonies were randomly isolated from MRS plates and characterized by a sequencing analysis of the 16S rRNA region and PFGE analysis of the DNA with the restriction NotI and SgsI enzymes (Thermo Fisher Scientific, Waltham, MA, USA) [14].

\subsection{RNA Extraction and Gene Expression Assay}

One $\mathrm{mL}$ of each of the samples stored at $-80^{\circ} \mathrm{C}$ for gene expression analysis purposes was thawed in refrigeration $\left(4^{\circ} \mathrm{C}\right)$. Later, RNA was extracted according to the instructions of the MasterPure ${ }^{\mathrm{TM}}$ Complete DNA and RNA Purification Kit (Epicentre, Madison, WI, USA), after centrifuging $1 \mathrm{~mL}$ aliquot $\left(10,000 \mathrm{rpm}, 10 \mathrm{~min}\right.$ at $\left.4{ }^{\circ} \mathrm{C}\right)$ and removing the resultant supernatant. To remove genomic DNA contamination, samples were treated with the RNAse-Free Dnase I (Epicentre). RNA concentration and purity $\left(\mathrm{A}_{260 / 280}\right)$ were then measured using the Nanodrop ${ }^{\mathrm{TM}}$ (Thermo Fisher Scientific). Complementary DNA (cDNA) was synthesized using about $500 \mathrm{ng}$ of the total extracted RNA according to the manufacturer's instructions for the PrimeScript ${ }^{\mathrm{TM}}$ RT Reagent Kit (Takara Bio Inc., Kusatsu, Shiga, Japan).

Quantitative PCR (qPCR) based on TaqMan ${ }^{\circledR}$ methodology was then used to amplify the virulence-related genes of L. monocytogenes, plcA, hly, and iap following the method described by Alía et al. [17]. In addition, a RT-qPCR based on SYBR ${ }^{\circledR}$ Green methodology was also performed to amplify the constitutive 16S rRNA gene used to ensure that both RNA extraction and cDNA synthesis processes were properly carried out according to Alía et al. [43]. The ViiA ${ }^{\mathrm{TM}} 7$ system (Applied Biosystems, Waltham, MA, USA) was used for qPCR performance. The reactions were prepared in MicroAmp ${ }^{\circledR}$ Fast Optical 96-Well Reaction plates (Applied Biosystems). Five replicates of RNA from control samples (only L. monocytogenes) and template-free negative controls (ultra-pure water instead of cDNA) were also included in the runs. Data analysis on the absolute expression of the target genes were determined using ViiA ${ }^{\mathrm{TM}} 7$ V.1.2.2 Software (Thermo Fisher Scientific). The quantification cycle $(\mathrm{Cq})$, the intersection between each fluorescence curve and a threshold line, was automatically calculated by the instrument using default parameters. The absolute expression levels of the three target genes from the different batches were extrapolated from the standard curves built for each gene as described by Alía et al. [17] by using the $\mathrm{Cq}$ values obtained for the samples. The absolute gene expression of each sample was evaluated in quintuplicate.

\subsection{Physicochemical Analysis}

The determination of $\mathrm{pH}$ and $\mathrm{a}_{\mathrm{w}}$ was carried out only in the batch inoculated with $L$. sakei 205 (batch B). The $\mathrm{pH}$ value was recorded after homogenizing $3 \mathrm{~g}$ of each sample with $27 \mathrm{~mL}$ of distilled water with a digital pH-meter Crison Basic 20 (Crison, Barcelona, Spain), while $\mathrm{a}_{\mathrm{w}}$ was determined on sausage slices using a Novasina Lab Master Water activity meter model AW SPRINT-TH 300 (Novasina AG, Lachen, Switzerland).

\subsection{Statistical Analysis}

Statistical analyses were performed using the software IBM SPSS Statistic for Windows v.22.0 (IBM, New York, NY, USA). The different batches and days of ripening were used as independent variables. The counts (Log CFU/g), $\mathrm{a}_{\mathrm{w}}, \mathrm{pH}$ values, and absolute expression were analyzed as dependent variables. Once the dependent and independent variables of the analysis were determined, a study of the normality of the different data populations 
was carried out using the Shapiro Wilk test. The analysis of the data was conducted using the Mann-Whitney test [44], and the statistical significance was set at $p \leq 0.05$.

\section{Results and Discussion}

\subsection{Evolution of Water Activity and pH during Ripening of "Salchichón"}

The $\mathrm{a}_{\mathrm{w}}$ decreased $(p \leq 0.05)$ from an initial value of $0.947 \mathrm{a}_{\mathrm{w}}$ in the raw product to values below $0.790 \mathrm{a}_{\mathrm{w}}$ at day 90 (Figure 2). The evolution of $\mathrm{a}_{\mathrm{w}}$ was similar to that reported for dry-cured fermented sausages by previous studies [45,46].

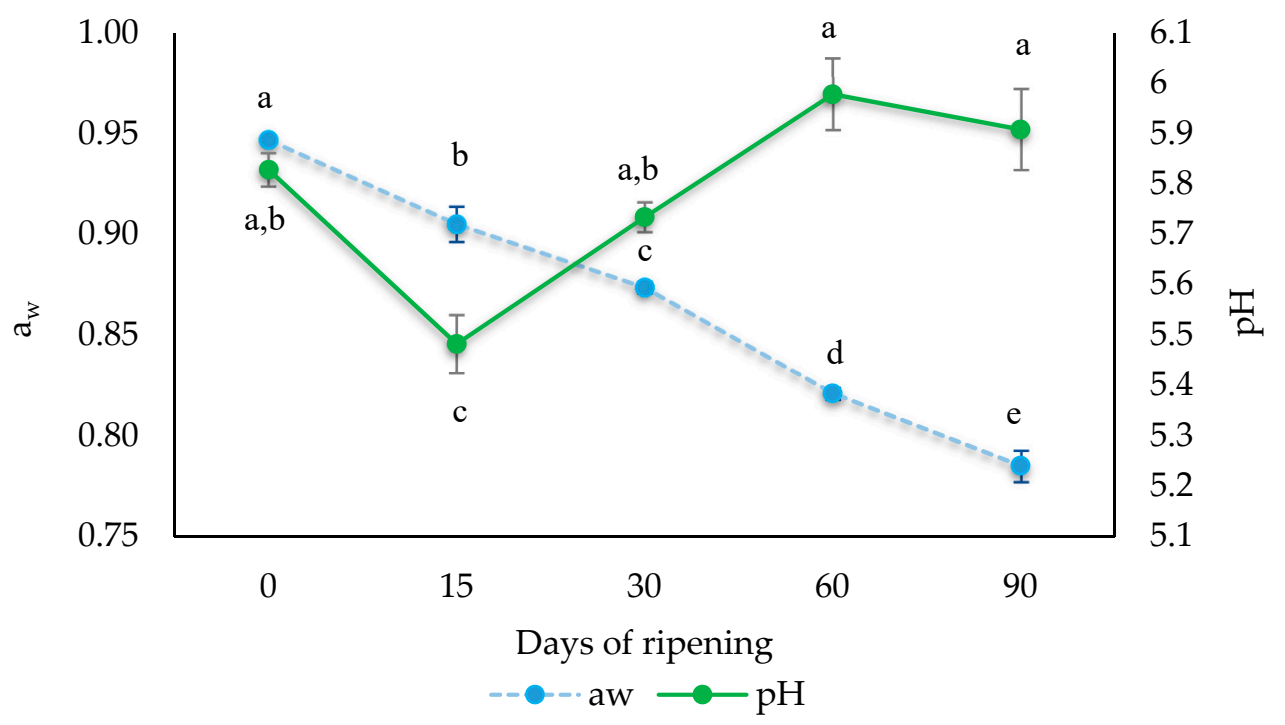

Figure 2. Evolution of water activity $\left(\mathrm{a}_{\mathrm{w}}\right)$ and $\mathrm{pH}$ of dry-cured fermented sausages "salchichón" throughout the ripening process. Different letters indicate significant differences in the same parameter at the different ripening days $(p \leq 0.05)$.

The evolution of $\mathrm{pH}$ throughout the ripening process of "salchichón" is shown in Figure 2. A decrease in $\mathrm{pH}$ values is observed after 15 days of ripening from 5.82 to $5.48(p \leq 0.05)$, probably due to the growth of the inoculated L. sakei 205. However, at day 30 of ripening, an increase in the $\mathrm{pH}$ value was observed (close to 5.8), and it then remained constant until the end of maturation. The increase in $\mathrm{pH}$ at the end of the ripening time may be due to the accumulation of non-protein nitrogen and amino acid catabolism products $[47,48]$.

\subsection{Evolution of Lactic-Acid Bacteria and L. monocytogenes Counts throughout the Ripening Process of "Salchichón"}

The evolution of LAB counts in L. sakei 205-inoculated batches (batches B and L + B) was very similar, since levels varied between 6.5 and $7.5 \log \mathrm{CFU} / \mathrm{g}$ in both batches during all the ripening times (Figure 3). There were no significant differences ( $p \leq 0.05$ ) in $\mathrm{LAB}$ counts between these two batches. However, in the batch inoculated only with L. monocytogenes (batch L), LAB counts were always lower than $6.5 \log \mathrm{CFU} / \mathrm{g}$, and for most of the ripening times were significantly lower $(p \leq 0.05)$ than those found in $L$. sakei 205-inoculated batches. These results were expected because of the inoculation with the selected L. sakei strain of dry-cured fermented sausages "salchichón" composing batches $\mathrm{B}$ and $\mathrm{L}+\mathrm{B}$. In batches inoculated with $L$. sakei $(\mathrm{B}$ and $\mathrm{L}+\mathrm{B})$, most of the tested isolates $(86 \%)$ were identified as L. sakei (100\% identity) by a sequencing analysis of the $16 \mathrm{~S}$ rRNA region. In the PFGE analysis, these isolates showed the same pattern of L. sakei 205. The remaining strains were Lactilactobacillus plantarum group (7\%) and Lactilactobacillus curvatus (7\%). In batch $L$, none of the isolates were identified as $L$. sakei. Thus, the inoculated L. sakei 205 was the predominant strain in L. sakei-inoculated bathes (B and B + L) and it was not detected in the batch inoculated only with L. monocytogenes (L). 


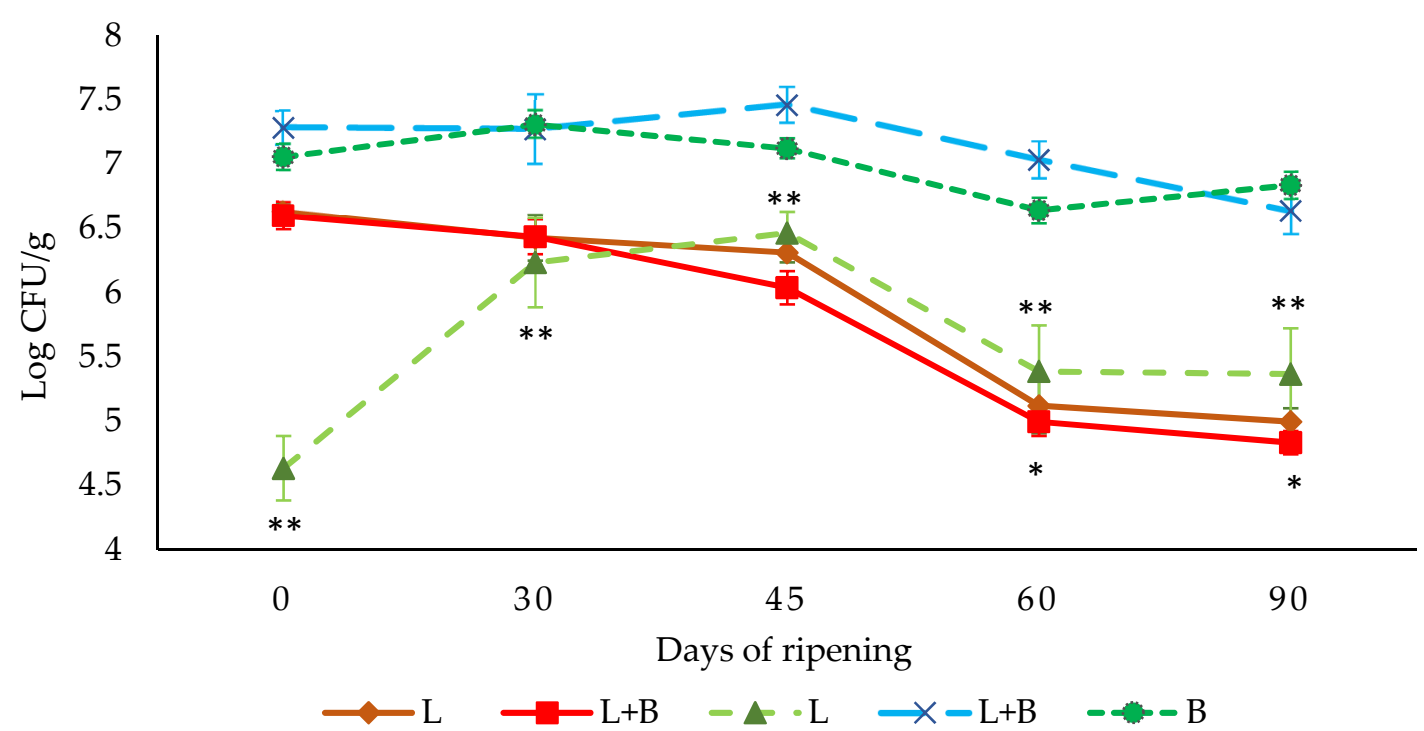

Figure 3. Growth curves of the LAB populations (dashed line) during the ripening process of dry-fermented sausages for batch B $(\bullet), \mathrm{L}(\Delta)$ and batch $\mathrm{L}+\mathrm{B}(\mathrm{X})$ and L. monocytogenes populations (solid line) for batch $\mathrm{L}(\diamond)$ and batch $\mathrm{L}+\mathrm{B}(\square)$. $\left(^{*}\right)$ indicates significant differences $(p \leq 0.05)$ between batches of L. monocytogenes and $(* *)$ between batches of LAB.

Levels of L. monocytogenes decreased $(p \leq 0.05)$ in both inoculated batches ( $\mathrm{L}$ and $\mathrm{L}$ + B) throughout the ripening process of the dry-cured fermented sausage "salchichón" (Figure 3). No increase in L. monocytogenes growth during the processing was observed in batches inoculated with this pathogen alone (L) or together with L. sakei 205 (L + B) (Figure 3), even considering that during the first 15 days of ripening, there could be certain conditions such as temperature $\left(7^{\circ} \mathrm{C}\right), \mathrm{a}_{\mathrm{w}}(0.947-0.914)$, and $\mathrm{pH}(5.8-5.4)$ that may allow the growth of L. monocytogenes. Likely, the synergistic effect of $\mathrm{a}_{\mathrm{w}}$, temperature, and $\mathrm{pH}$ reduction together with the effect of $\mathrm{NaCl}$ and nitrite added, and the presence of $\mathrm{LAB}$ inoculated or from contamination, prevent the growth of L. monocytogenes in the first days of ripening $[38,49,50]$. After 15 days of processing, the $a_{w}$ values of "salchichón", ranging from 0.914 to $0.779 \mathrm{a}_{\mathrm{w}}$, did not allow the growth of L. monocytogenes [51,52]. From day 45 until the end of ripening, levels of $L$. monocytogenes were significantly lower in the batch inoculated with L. sakei $205(\mathrm{~L}+\mathrm{B})$ than in the batch only inoculated with $L$. monocytogenes (L). This additional reduction in L. monocytogenes can be associated with the presence of the strain L. sakei 205. Different strains of this species have shown anti-microbial effects when they have been used as protective cultures $[30,38,40]$. In this work, a reduction of about $2 \log \mathrm{CFU} / \mathrm{g}$ was achieved during the processing of dry-cured fermented sausage "salchichón". This means that this pathogenic bacterium could be detected after 90 days of ripening if the levels of contamination in raw materials or during processing are higher than $2 \log \mathrm{CFU} / \mathrm{g}$. Thus, it is of great importance to evaluate the effect of processing in the expression of virulence genes of L. monocytogenes.

3.3. Effect of Processing and Presence of L. sakei on the Absolute Transcription Levels of $L$. monocytogenes Virulence Genes in Dry-Cured Fermented Sausages

Findings on this work revealed a high and significant relationship between the transcriptomic response and counts of L. monocytogenes ( $r$-values: $0.792,0.821$, and 0.820 for the $p l c A, h l y$, and iap genes, respectively). The two virulence genes $p l c A$ and $h l y$ showed higher expression values than those found for the iap gene in all the tested conditions $(p \leq 0.05$; Table 1). In addition, at 0,15 , and 30 days of processing, no differences $(p>0.05)$ in the gene expression values were found for all the analysed batches (Table 1). However, at days 60 and 90 of ripening, a significant decrease in the transcription levels regarding days 0,15 , and 30 was detected for all the analysed genes. 
Table 1. Absolute expression values (mean log copies of gene \pm standard deviation) of the virulence (plcA, hly, and iap) genes of Listeria monocytogenes in dry-cured fermented sausages "salchichón" throughout the ripening process. Batches: L: L. monocytogenes, L + B: L. monocytogenes + Lactilactobacillus sakei 205. The assays were conducted in quintuplicate.

\begin{tabular}{ccccccc}
\hline \multirow{2}{*}{ Genes } & \multirow{2}{*}{ Batches } & \multicolumn{5}{c}{ Days of Ripening } \\
\cline { 2 - 6 } & & $\mathbf{0}$ & $\mathbf{1 5}$ & $\mathbf{3 0}$ & $\mathbf{6 0}$ & $\mathbf{9 0}$ \\
\hline \multirow{2}{*}{$h l y$} & $\mathrm{~L}$ & $3.01 \pm 0.372^{1}$ & $3.07 \pm 0.099^{1}$ & $3.26 \pm 0.216^{1}$ & $1.89 \pm 0.226^{2, \mathrm{~b}}$ & $1.82 \pm 0.370^{2}$ \\
\cline { 2 - 6 } & $\mathrm{L}+\mathrm{B}$ & $3.28 \pm 0.132^{1,2}$ & $2.96 \pm 0.180^{2}$ & $3.42 \pm 0.208^{1}$ & $2.48 \pm 0.272^{3, \mathrm{a}}$ & $1.49 \pm 0.316^{4}$ \\
\hline \multirow{2}{*}{ plcA } & $\mathrm{L}$ & $4.17 \pm 0.286^{1}$ & $4.32 \pm 0.282^{1, \mathrm{a}}$ & $4.41 \pm 0.410^{1}$ & $2.47 \pm 0.236^{2}$ & $3.06 \pm 0.505^{2}$ \\
\cline { 2 - 6 } & $\mathrm{L}+\mathrm{B}$ & $4.01 \pm 0.265^{1}$ & $3.74 \pm 0.440^{1, \mathrm{~b}}$ & $4.35 \pm 0.271^{1}$ & $2.91 \pm 0.494^{2}$ & $2.68 \pm 0.483^{2}$ \\
\hline \multirow{2}{*}{ iap } & $\mathrm{L}$ & $2.72 \pm 0.181^{1}$ & $2.69 \pm 0.067^{1}$ & $2.82 \pm 0.283^{1}$ & $1.65 \pm 0.368^{2}$ & $1.96 \pm 0.249^{2}$ \\
\cline { 2 - 6 } & $\mathrm{L}+\mathrm{B}$ & $2.92 \pm 0.165^{1}$ & $2.70 \pm 0.076^{1}$ & $3.16 \pm 0.378^{1}$ & $1.66 \pm 0.433^{2}$ & $1.53 \pm 0.491^{2}$ \\
\hline
\end{tabular}

Within column, different superscript letters denote significant differences for the same gene in each batch at the different ripening days $(p \leq 0.05)$. Within row, different superscript numbers denote significant differences for the same gene and batch at each ripening day $(p \leq 0.05)$

These results showed that the virulence gene expression values decreased at the end of the ripening period, likely due to the stress conditions created due to the processing and composition of "salchichón" mainly characterized by the decrease in $\mathrm{a}_{\mathrm{w}}$ throughout the ripening until values below $0.85 \mathrm{a}_{\mathrm{w}}$. A decrease in the $p l c A$, hly, and iap gene expression values has been reported in a dry-cured ham model system as a consequence of $\mathrm{a}_{\mathrm{w}}$ decrease [19]. Furthermore, a downregulation in the expression of $p l c A$ and hly genes has been reported in different stress conditions on dry-cured meat products, likely due to the $\operatorname{prfA}$ gene repression, the major regulator of L. monocytogenes virulence [6,53]. Thus, at the end of "salchichón" ripening with $\mathrm{a}_{\mathrm{w}}$ below $0.85 \mathrm{a}_{\mathrm{w}}$, the expression of stress-related genes is likely enhanced, and the transcription of other non-stress-related genes such as virulence genes is repressed to facilitate the L. monocytogenes survival in highly stressful environments, as has been previously reported [6,54]. This agrees with the results obtained in this study, since it has been observed that the expression of the three virulence genes tested decreased. These findings are very interesting, since they correspond to real food samples. Most published works that showed an up-regulation in virulence genes of L. monocytogenes were in vitro-conducted with laboratory-based media [6]. However, the food matrix, especially a meat-based one, may influence the virulence potential of L. monocytogenes, possibly through the downregulation of virulence genes $[6,21,55]$. In addition, Bowman et al. [53] reported the suppression of $\operatorname{prf} A$ and sigB genes because of the non-thermal treatment on L. monocytogenes; this may also explain the decrease in the expression levels of $p l c A$ and hly genes.

When the effect of the inoculated L. sakei 205 on the expression of virulence genes tested was analyzed, the expression values of the three genes remained constant compared to those obtained in the control batch (L), except at day 60 of maturation, when significantly higher expression values were detected for the hly gene in batch $\mathrm{L}+\mathrm{B}$ (Table 1). In addition, no differences between these two batches were found at the end of the ripening time (Table 1). These results contrast with the demonstrated effect of some bacteriocinogenic LAB such as Enterococcus faecium on the inhibition of the expression of the virulence genes of L. monocytogenes [56]. In the present work, L. sakei 205, which provokes an additional decrease in L. monocytogenes counts to those produced by the action of the reduction in $\mathrm{pH}$ and $\mathrm{a}_{\mathrm{w}}$ throughout the ripening of "salchichón", does not show any appreciable effect on the virulence gene expression of L. monocytogenes throughout this processing. To be used as a protective culture, it is important that L. sakei 205 does not cause an increase in the virulence gene expression of this pathogenic bacterium, since in some cases, various protective cultures such as selected strains of Debaryomyces hansenii have been reported to enhance the expression of virulence genes on L. monocytogenes [19]. 
In the present work, it has been demonstrated that a reduction in L. monocytogenes counts throughout the ripening process and a downregulation in the expression of virulence genes of the pathogenic bacterium cells could survive dry-cured fermented processing, but this effect was not increased by the addition of the strain L. sakei 205. The last effect is of great importance, since reports the relevance of the virulence gene transcription on the invasive and survival ability of L. monocytogenes in human models or cell lines [20-24]. Although further studies should be carried out to evaluate the effect of L. monocytogenes surviving "salchichón" ripening in culture cells, the processing of this product to reach $\mathrm{a}_{\mathrm{w}}$ values below $0.85 \mathrm{a}_{\mathrm{w}}$ seems to be effective to control the microbial hazard caused by the presence of L. monocytogenes.

\section{Conclusions}

This study describes for the first time the combined effect of the processing of "salchichón" manufactured with a selected protective culture of $L$. sakei on minimizing the growth and expression of three virulence genes ( $p l c A, h l y$, and iap) of L. monocytogenes. The processing of "salchichón" provokes a reduction of $2 \log \mathrm{CFU} / \mathrm{g}$ of L. monocytogenes. L. sakei 205 provokes an additional decrease in L. monocytogenes counts to those produced by the action of the reduction in $\mathrm{pH}$ and $\mathrm{a}_{\mathrm{w}}$ throughout the ripening of "salchichón". In addition, when the $\mathrm{a}_{\mathrm{w}}$ of the product is lower than $0.85 \mathrm{a}_{\mathrm{w}}$, a downregulation in the expression of the above virulence genes was found. However, L. sakei 205 does not show any appreciable effect on the virulence gene expression of L. monocytogenes throughout "salchichón" processing. The combined effects of the reduction in L. monocytogenes throughout the procession of "salchichón" and the downregulation of the virulence gene expression of the surviving strains of this pathogen are relevant to control L. monocytogenes in this product.

Author Contributions: Conceptualization, J.J.C. and A.R.; methodology, I.M.; software, A.A.; validation, I.M., A.A. and F.G.; formal analysis, I.M., A.A. and F.G.; investigation, I.M.; resources, A.R. and J.J.C.; data curation, I.M.; writing—original draft preparation, I.M. and J.J.C.; writing-review and editing, I.M., A.R., A.A., F.G. and J.J.C.; visualization, I.M.; supervision, A.R. and J.J.C.; project administration, J.J.C. and A.R.; funding acquisition, J.J.C. All authors have read and agreed to the published version of the manuscript.

Funding: This research was funded by the Spanish Ministry of Economy, Industry, and Competitiveness (RTA-2017-00027-C03-03); the Spanish Ministry of Education, Culture, and Sports (FPU 16/05303); and the Junta De Extremadura and Feder (IB16149, GR15108 and GR18056).

Institutional Review Board Statement: Not applicable.

Informed Consent Statement: Not applicable.

Data Availability Statement: Not applicable.

Acknowledgments: This work was supported by the INIA throughout the projects RTA-2017-00027C03-03 (Spanish Ministry of Economy, Industry, and Competitiveness) and the Junta de Extremadura and FEDER by IB16149, GR15108, and GR18056. I. Martín is supported by a pre-doctoral fellowship from the Spanish Ministry of Education, Culture and Sports (FPU 16/05303).

Conflicts of Interest: The authors declare no conflict of interest.

\section{References}

1. Filipello, V.; Gallina, S.; Amato, E.; Losio, M.N.; Pontello, M.; Decastelli, L.; Lomonaco, S. Diversity and persistence of Listeria monocytogenes within the Gorgonzola PDO production chain and comparison with clinical isolates from the same area. Int. J. Food Microbiol. 2017, 245, 73-78. [CrossRef] [PubMed]

2. Kathariou, S. Listeria monocytogenes virulence and pathogenicity, a food safety perspective. J. Food Prot. 2002, 65, 1811-1829. [CrossRef] [PubMed]

3. Alía, A.; Andrade, M.J.; Rodríguez, A.; Martín, I.; Pérez-Baltar, A.; Medina, M.; Córdoba, J.J. Prevalence and characterization of Listeria monocytogenes in deboning and slicing areas of Spanish dry-cured ham processing. LWT-Food Sci. Technol. 2020, 128, 109498. [CrossRef] 
4. Samelis, J.; Bedie, G.K.; Sofos, J.N.; Belk, K.E.; Scanga, J.A.; Smith, G.C. Control of Listeria monocytogenes with combined antimicrobials after postprocess contamination and extended storage of frankfurters at $4{ }^{\circ} \mathrm{C}$ in vacuum packages. J. Food Prot. 2002, 65, 299-307. [CrossRef]

5. EURL Lm Technical Guidance Document on Challenge Test and Durability Studies for Assessing Shelf-Life of Ready-to Eat Foods Related to Listeria monocytogenes. 2021. Available online: https:/ / ec.europa.eu/food/system/files/2021-07/biosafety_fh_mc_ tech-guide-doc_listeria-in-rte-foods_en_0.pdf (accessed on 28 July 2021).

6. Mataragas, M.; Rovetto, F.; Bellio, A.; Alessandria, V.; Rantsiou, K.; Decastelli, L.; Cocolin, L. Differential gene expression profiling of Listeria monocytogenes in cacciatore and felino salami to reveal potential stress resistance biomarkers. Food Microbiol. 2015, 46, 408-417. [CrossRef]

7. Janßen, D.; Eisenbach, L.; Ehrmann, M.A.; Vogel, R.F. Assertiveness of Lactobacillus sakei and Lactobacillus curvatus in a fermented sausage model. Int. J. Food Microbiol. 2018, 285, 188-197. [CrossRef]

8. Martín, B.; Jofré, A.; Garriga, M.; Pla, M.; Aymerich, T. Rapid quantitative detection of Lactobacillus sakei in meat and fermented sausages by real-time PCR. Appl. Environ. Microbiol. 2006, 72, 6040-6048. [CrossRef]

9. Barmpalia-Davis, I.M.; Geornaras, I.; Kendall, P.A.; Sofos, J.N. Survival of Listeria monocytogenes in a simulated dynamic gastrointestinal model during storage of inoculated Bologna and Salami slices in vacuum packages. J. Food Prot. 2008, 71, 2014-2023. [CrossRef]

10. Doménech, E.; Jimenez-Belenguer, A.; Amoros, J.A.; Ferrus, M.A.; Escriche, I. Prevalence and antimicrobial resistance of Listeria monocytogenes and Salmonella strains isolated in ready-to-eat foods in Eastern Spain. Food Control. 2015, 47, 120-125. [CrossRef]

11. Ferreira, V.; Barbosa, J.; Silva, J.; Felício, M.T.; Mena, C.; Hogg, T.; Gibbs, P.; Teixeira, P. Characterisation of alheiras, traditional sausages produced in the North of Portugal, with respect to their microbiological safety. Food Control. 2007, 18, 436-440. [CrossRef]

12. Meloni, D. Presence of Listeria monocytogenes in mediterranean-style dry fermented sausages. Foods 2015, 4, 34-50. [CrossRef]

13. Foodborne Ilness Outbreak Database Siena Foods Salame. Available online: http:/ /www.outbreakdatabase.com/details/assimarket-pickles-2010/ ?vehicle=cucumber (accessed on 26 June 2021).

14. Martín, I.; Rodríguez, A.; Sánchez-Montero, L.; Padilla, P.; Córdoba, J.J. Effect of the dry-cured fermented sausage "salchichón" processing with a selected Lactobacillus sakei in Listeria monocytogenes and microbial population. Foods 2021, 10, 856. [CrossRef]

15. Commission, E. Commission Regulation (EC) No 1441/2007 of 5 December 2007 amending Regulation (EC) No 2073/2005 on microbiological criteria for foodstuff. Off. J. Eur. Communities 2007, 322, 12-29.

16. Rolhion, N.; Cossart, P. How the study of Listeria monocytogenes has led to new concepts in biology. Futur. Microbiol. Futur. Med. 2017, 12, 621-638. [CrossRef] [PubMed]

17. Alía, A.; Rodríguez, A.; Andrade, M.J.; Gómez, F.; Córdoba, J.J. Combined effect of temperature, water activity and salt content on the growth and gene expression of Listeria monocytogenes in a dry-cured ham model system. Meat Sci. 2019, 155, 16-19. [CrossRef] [PubMed]

18. Hadjilouka, A.; Molfeta, C.; Panagiotopoulou, O.; Paramithiotis, S.; Mataragas, M.; Drosinos, E.H. Expression of Listeria monocytogenes key virulence genes during growth in liquid medium, on rocket and melon at 4,10 and $30{ }^{\circ} \mathrm{C}$. Food Microbiol. 2016, 55, 7-15. [CrossRef]

19. Alía, A.; Córdoba, J.J.; Rodríguez, A.; García, C.; Andrade, M.J. Evaluation of the efficacy of Debaryomyces hansenii as protective culture for controlling Listeria monocytogenes in sliced dry-cured ham. LWT 2020, 119, 108886. [CrossRef]

20. Olesen, I.; Vogensen, F.; Jespersn, L. Gene Transcription and virulence potential of Listeria monocytogenes strains after exposure to acidic and $\mathrm{NaCl}$ stress. Foodborne Pathog. Dis. 2009, 6, 669-680. [CrossRef]

21. Olesen, I.; Thorsen, L.; Jespersen, L. Relative transcription of Listeria monocytogenes virulence genes in liver pâtés with varying $\mathrm{NaCl}$ content. Int. J. Food Microbiol. 2010, 141, S60-S68. [CrossRef] [PubMed]

22. Garner, M.R.; James, K.E.; Callahan, M.C.; Wiedmann, M.; Boor, K.J. Exposure to salt and organic acids increases the ability of Listeria monocytogenes to invade Caco-2 cells but decreases its ability to survive gastric stress. Appl. Environ. Microbiol. 2006, 72, 5384-5395. [CrossRef]

23. Kang, J.; Burall, L.; Mammel, M.K.; Datta, A.R. Global transcriptomic response of Listeria monocytogenes during growth on cantaloupe slices. Food Microbiol. 2019, 77, 192-201. [CrossRef] [PubMed]

24. Lin, C.S.; Wang, C.; Tsai, H.J.; Chou, C.H. Growth of Listeria monocytogenes on a RTE-meat matrix enhances cell invasiveness to mouse J774A.1 macropahges. Int. J. Food Microbiol. 2010, 144, 199-201. [CrossRef]

25. Upadhyay, A.; Johny, A.K.; Amalaradjou, M.A.R.; Baskaran, S.A.; Kim, K.S.; Venkitanarayanan, K. Plant-derived antimicrobials reduce Listeria monocytogenes virulence factors in vitro, and down-regulate expression of virulence genes. Int. J. Food Microbiol. 2012, 157, 88-94. [CrossRef]

26. Delgado, J.; Peromingo, B.; Rodríguez, A.; Rodríguez, M. Biocontrol of Penicillium griseofulvum to reduce cyclopiazonic acid contamination in dry-fermented sausages. Int. J. Food Microbiol. 2019, 293, 1-6. [CrossRef]

27. Mataragas, M.; Alessandria, V.; Rantsiou, K.; Cocolin, L. Evaluation of the Listeria monocytogenes inactivation during post-process storage of fermented sausages: A basis for the development of a decision support tool. Food Control. 2015, 50, 568-573. [CrossRef]

28. Cano-García, L.; Belloch, C.; Flores, M. Impact of Debaryomyces hansenii strains inoculation on the quality of slow dry-cured fermented sausages. Meat Sci. 2014, 96, 1469-1477. [CrossRef] [PubMed]

29. Martín, A.; Córdoba, J.J.; Aranda, E.; Córdoba, M.G.; Asensio, M.A. Contribution of a selected fungal population to the volatile compounds on dry-cured ham. Int. J. Food Microbiol. 2006, 110, 8-18. [CrossRef] 
30. Zagorec, M.; Champomier-Vergès, M.-C. Lactobacillus sakei: A starter for sausage fermentation, a protective culture for meat products. Microorganisms 2017, 5, 56. [CrossRef]

31. Kurbakov, K.A.; Konorov, E.A.; Minaev, M.Y.; Kuznetsova, O.A. Multiplex real-time PCR with HRM for detection of Lactobacillus sakei and Lactobacillus curvatus in Food Samples. Food Technol. Biotechnol. 2019, 57, 97-104. [CrossRef]

32. Prado, N.; Sampayo, M.; González, P.; Lombó, F.; Díaz, J. Physicochemical, sensory and microbiological characterization of Asturian Chorizo, a traditional fermented sausage manufactured in Northern Spain. Meat Sci. 2019, 156, 118-124. [CrossRef]

33. Quijada, N.M.; De Filippis, F.; Sanz, J.J.; García-Fernández, M.D.C.; Rodríguez-Lázaro, D.; Ercolini, D.; Hernández, M. Different Lactobacillus populations dominate in "Chorizo de León" manufacturing performed in different production plants. Food Microbiol. 2018, 70, 94-102. [CrossRef]

34. Sidira, M.; Mitropoulou, G.; Galanis, A.; Kanellaki, M.; Kourkoutas, Y. Effect of Sugar Content on Quality Characteristics and Shelf-Life of Probiotic Dry-Fermented Sausages Produced by Free or Immobilized Lactobacillus casei ATCC 393. Foods 2019,8 , 219. [CrossRef] [PubMed]

35. Sobrino, O.J.; Rodríguez, J.M.; Moreira, W.L.; Fernández, M.F.; Sanz, B.; Hernández, P.E. Antibacterial activity of Lactobacillus strains isolated from dry fermented sausages. Int. J. Food Microbiol. 1993, 75, 344-349. [CrossRef]

36. Lucke, F.K. Utilization of microbes to process and preserve meat. Meat Sci. 2000, 56, 105-115. [CrossRef]

37. Chaillou, S.; Champomier-Vergès, M.C.; Cornet, M.; Crutz-Le Coq, A.M.; Dudez, A.M.; Martin, V.; Beaufils, S.; Darbon-Rongère, E.; Bossy, R.; Loux, V. The complete genome sequence of the meat-borne lactic acid bacterium Lactobacillus sakei 23K. Nat. Biotechnol. 2005, 23, 1527-1533. [CrossRef] [PubMed]

38. Bošković, M.; Tadić, V.; Dordević, J.; Glišić, M.; Lakićević, B.; Dimitrijević, M.; Ž Baltić, M. Effect of starter cultures on survival of Listeria monocytogenes in Čajna sausage. IOP Conf. Ser. Earth Environ. Sci. 2017, 85, 012074. [CrossRef]

39. Prpich, N.Z.P.; Garro, O.A.; Romero, M.; Judis, M.A.; Cayré, M.E.; Castro, M.P. Evaluation of an autochthonous starter culture on the production of a traditional dry fermented sausage from Chaco (Argentina) at a small-scale facility. Meat Sci. 2016, 115, 41-44. [CrossRef]

40. Prpich, N.Z.P.; Castro, M.P.; Cayré, M.E.; Garro, O.A.; Vignolo, G.M. Indigenous starter cultures to improve quality of artisanal dry fermented sausages from chaco (Argentina). Int. J. Food Sci. 2015, 2015, 1-9. [CrossRef] [PubMed]

41. Mataragas, M.; Greppi, A.; Rantsiou, K.; Cocolin, L. Gene Transcription patterns of pH and salt stressed Listeria monocytogenes cells in simulated gastric and pancreatic conditions. J. Food Prot. 2014, 77, 254-261. [CrossRef]

42. Beaufort, A.; Cornu, M.; Bergis, H.; Lardeux, A.L.; Lombard, B. EURL Lm Technical Guidance Document for Conducing Shelf-life Studies on Listeria monocytogenes in Ready to Eat Foods. Available online: https://www.fsai.ie/uploadedFiles/EURL\%20Lm_ Technical\%20Guidance\%20Document\%20Lm\%20shelf-life\%20studies_V3_2014-06-06\%20(2).pdf (accessed on 6 November 2021).

43. Alía, A.; Andrade, M.J.; Córdoba, J.J.; Martín, I.; Rodríguez, A. Development of a multiplex real-time PCR to differentiate the four major Listeria monocytogenes serotypes in isolates from meat processing plants. Food Microbiol. 2020, 87, 856. [CrossRef] [PubMed]

44. Mann, H.B.; Whitney, D. On a test of whether one of two random variables is stochastically larger than the other. Ann. Math. Stat. 1947, 2, 347-370. [CrossRef]

45. Casquete, R.; Benito, M.J.; Martín, A.; Ruiz-Moyano, S.; Hernández, A.; Córdoba, M.G. Effect of autochthonous starter cultures in the production of "salchichón", a traditional Iberian dry-fermented sausage, with different ripening processes. LWT-Food Sci. Technol. 2011, 44, 1562-1571. [CrossRef]

46. El Adab, S.; Essid, I.; Hassouna, M. Microbiological, biochemical and textural characteristics of a tunisian dry fermented poultry meat sausage inoculated with selected starter cultures. J. Food Saf. 2015, 35, 75-85. [CrossRef]

47. Aleson-Carbonell, L.; Fernández-López, J.; Pérez-Alvarez, J.A.; Kuri, V. Functional and sensory effects of fibre-rich ingredients on breakfast fresh sausages manufacture. Food Sci. Technol. Int. 2005, 11, 89-97. [CrossRef]

48. Pérez-Álvarez, J.A.; Sayas-Barberá, M.E.; Fernández-López, J.; Aranda-Catalá, V. Physicochemical characteristics of Spanish-type dry-cured sausage. Food Res. Int. 1999, 32, 599-607. [CrossRef]

49. Benkerroum, N.; Daoudi, A.; Hamraoui, T.; Ghalfi, H.; Thiry, C.; Duroy, M.; Evrart, P.; Roblain, D.; Thonart, P. Lyophilized preparations of bacteriocinogenic Lactobacillus curvatus and Lactococcus lactis subsp. lactis as potential protective adjuncts to control Listeria monocytogenes in dry-fermented sausages. J. Appl. Microbiol. 2005, 98, 56-63. [CrossRef] [PubMed]

50. Pavli, F.G.; Argyri, A.A.; Chorianopoulos, N.G.; Nychas, G.J.E.; Tassou, C.C. Effect of Lactobacillus plantarum L125 strain with probiotic potential on physicochemical, microbiological and sensorial characteristics of dry-fermented sausages. LWT 2020, 118, 108810. [CrossRef]

51. Nolan, D.A.; Chamblin, D.C.; Troller, J.A. Minimal water activity levels for growth and survival of Listeria monocytogenes and Listeria innocua. Int. J. Food Microbiol. 1992, 16, 323-335. [CrossRef]

52. Vermeulen, A.; Gysemans, K.P.M.; Bernaerts, K.; Geeraerd, A.H.; Van Impe, J.F.; Debevere, J.; Devlieghere, F. Influence of pH, water activity and acetic acid concentration on Listeria monocytogenes at $7^{\circ} \mathrm{C}$ : Data collection for the development of a growth/no growth model. Int. J. Food Microbiol. 2007, 114, 332-341. [CrossRef]

53. Bowman, J.P.; Bittencourt, C.R.; Ross, T. Differential gene expression of Listeria monocytogenes during high hydrostatic pressure processing. Microbiology 2008, 154, 462-475. [CrossRef]

54. Jiang, L.; Olesen, I.; Andersen, T.; Fang, W.; Jespersen, L. Survival of Listeria monocytogenes in simulated gastrointestinal system and transcriptional profiling of stress- and adhesion-related genes. Foodborne Pathog. Dis. 2010, 7, 267-274. [CrossRef] [PubMed] 
55. Mahoney, M.; Henriksson, A. The effect of processed meat and meat starter cultures on gastrointestinal colonization and virulence of Listeria monocytogenes in mice. Int. J. Food Microbiol. 2003, 84, 255-261. [CrossRef]

56. Ye, K.; Zhang, X.; Huang, Y.; Liu, J.; Liu, M.; Zhou, G. Bacteriocinogenic Enterococcus faecium inhibits the virulence property of Listeria monocytogenes. Food Sci. Technol. 2018, 89, 87-92. [CrossRef] 